\title{
Variation in egg spawning among subpopulations of sea urchins Strongylocentrotus droebachiensis: a theoretical approach
}

\author{
Susanne K. Meidel ${ }^{1, *}$, Robert E. Scheibling ${ }^{2}$ \\ ${ }^{1}$ Darling Marine Center, University of Maine, 193 Clarks Cove Road, Walpole, Maine 04573, USA \\ ${ }^{2}$ Department of Biology, Dalhousie University, Halifax, Nova Scotia B3H 4J1, Canada
}

\begin{abstract}
Variation in zygote production, by determining the initial size of the larval pool, can affect the population dynamics of marine invertebrates with a planktonic larval stage. In this paper, we model temporal and spatial patterns in egg spawning of the sea urchin Strongylocentrotus droebachiensis in the shallow subtidal zone along the Atlantic coast of Nova Scotia. In this region, population outbreaks of sea urchins have caused major transitions from kelp beds to barrens (areas devoid of fleshy macroalgae). We define 3 community states and associated subpopulations of sea urchins: (1) the established kelp bed state, where sea urchins are in low density and small; $(2)$ the transition state, with sea urchins in kelp beds, newly created (transitional) barrens, and grazing fronts (dense aggregations of large sea urchins along the edges of kelp beds); and (3) the barrens state after fronts have dispersed and intermediate densities of moderately sized sea urchins remain in post-transitional barrens. Using data from the literature and unpublished sources, we parameterize mathematical models to predict egg spawning for each subpopulation, both on an areal basis and for the entire coast. The predicted number of eggs spawned per $\mathrm{m}^{2}$ is 1 order of magnitude higher in grazing fronts $\left(7.1 \times 10^{7}\right)$ than in transitional and post-transitional barrens $\left(5.8 \times 10^{6}\right.$ and $4.4 \times 10^{6}$, respectively), and 4 to 6 times higher in barrens than in established kelp beds $\left(1.0 \times 10^{6}\right)$. Differences among subpopulations in the number of eggs spawned are directly related to differences in adult density, female gonad output, and body size. The total number of eggs spawned (all subpopulations combined) on a coastal scale increases $\sim 6$-fold from the established kelp bed state $\left(5.6 \times 10^{14}\right)$ to the late transition state $\left(3.1 \times 10^{15}\right)$ and then drops slightly in the barrens state $\left(2.4 \times 10^{15}\right)$. During most of the transition state, sea urchins in barrens spawn the greatest number of eggs. Based on published values, we estimate that fertilization rates are highest in grazing fronts $(62 \%)$, intermediate in transitional and post-transitional barrens (36 and $43 \%$, respectively) and lowest in kelp beds (15\%), resulting in up to 2 orders of magnitude differences in the number of zygotes produced in these subpopulations $\left(4.4 \times 10^{7}, 2.1 \times 10^{6}, 1.9 \times 10^{6}\right.$, and $1.5 \times 10^{5}$ ). Total zygote production (all subpopulations combined) on a coastal scale increases $\sim 16$-fold from the established kelp bed state $\left(8.1 \times 10^{13}\right)$ to the late transition state $\left(1.3 \times 10^{15}\right)$ and then drops slightly in the barrens state $\left(1.1 \times 10^{15}\right)$. During most of the transition state, sea urchins in barrens contribute the greatest number of zygotes to the total zygote pool, with those in grazing fronts contributing up to $44 \%$ of all zygotes. Sensitivity analysis and evaluation of model assumptions indicate that our predictions should be correct in a relative sense (i.e. comparing among subpopulations), although absolute numbers may be overestimated. A disparity between temporal patterns of estimated zygote production and observed settlement rates of $S$. droebachiensis in the shallow subtidal zone suggests that zygote production interacts with other factors to determine settlement rates of this species.
\end{abstract}

KEY WORDS: Sea urchins $\cdot$ Strongylocentrotus droebachiensis $\cdot$ Egg spawning $\cdot$ Fertilization rate Zygote production $\cdot$ Kelp beds $\cdot$ Barrens $\cdot$ Grazing fronts

Resale or republication not permitted without written consent of the publisher

\section{INTRODUCTION}

In marine benthic invertebrates with a planktonic larval stage, variation in the supply of settling larvae to

*E-mail: meidel@maine.edu adult populations is an important determinant of population structure and dynamics (e.g. Pearse \& Hines 1987, Minchinton \& Scheibling 1991, Grosberg \& Levitan 1992). The overall supply of settlers is fundamentally related to the total number of zygotes produced at a multitude of sites. Zygote production in free-spawn- 
ing marine invertebrates is determined by the number of eggs spawned and the proportion of those eggs that is fertilized. Both egg spawning and fertilization rates are influenced by a variety of environmental (e.g. food supply, hydrodynamic regime) and demographic factors (e.g. population density, size structure, gamete output), which show marked spatial and temporal variation among different adult populations. As a result, adult populations do not contribute equally to the overall pools of eggs and zygotes produced in a region. To date, there have been few attempts to evaluate how populations vary in their relative contribution to egg or zygote pools (Keats et al. 1984), or how the size of the pools may vary over time. Empirical analysis of this problem is hampered by logistical difficulties. However, an extensive body of work on factors that influence egg spawning in combination with an increased understanding of fertilization ecology (reviewed by Levitan 1995) and published fertilization estimates enable a theoretical approach.

Fecundity and fertilization rate, which together determine zygote production, are influenced by the simple and interactive effects of a variety of factors. Fecundity usually increases in both absolute and relative terms with body size (e.g. Gonor 1972, Kettle \& Lucas 1987, Meidel \& Scheibling 1998b) and with higher food quality and/or quantity (e.g. Vadas 1977, Scheibling 1981). A high density of spawning adults generally increases the number of eggs spawned per unit area although it may negatively influence body size or gamete output of individuals (Branham et al. 1971, Levitan 1988a, 1991, Wahle \& Peckham 1999). Fertilization rates have been shown to increase with adult density (Pennington 1985, Grosberg 1991, Levitan 1991, Oliver \& Babcock 1992, Yund 1995, Coma \& Lasker 1997) and in some cases with sperm production (Babcock et al. 1994, Yund 1998). Empirical (Pennington 1985, Levitan et al. 1992, Wahle \& Peckham 1999) and theoretical (Denny \& Shibata 1989, Young et al. 1992, Levitan \& Young 1995) studies have also indicated that a low flow regime during spawning increases fertilization rate by reducing gamete dilution.

Well-studied species which exhibit large fluctuations in population density, demography, and reproductive output are ideally suited for modelling variation in egg spawning and zygote production. One such species is the sea urchin Strongylocentrotus droebachiensis (Müller), for which changes in population size and structure have been well documented along the Atlantic coast of Nova Scotia over the last 3 decades (Lang \& Mann 1976, Wharton \& Mann 1981, Scheibling et al. 1999). When sea urchins are in low abundance, kelp beds (consisting mainly of the kelps Laminaria longicruris and $L$. digitata with an understory of coralline and fleshy macroalgae) thrive in the shallow rocky subtidal zone (Edelstein et al. 1969, Mann 1972). Sea urchins exposed to an abundance of food in the form of drift algae and small understory plants grow rapidly and produce large gonads (Lang \& Mann 1976, Meidel \& Scheibling 1998a,b). As the density of sea urchins increases, large individuals start to aggregate at the edge of kelp beds, forming fronts (Lang \& Mann 1976, Wharton 1980b, Bernstein et al 1981, Scheibling et al. 1994, 1999) which destructively graze the kelp. Sea urchins in fronts climb up onto plants, weigh them down and consume them entirely (Breen \& Mann 1976a, Mann 1977). The facilitative effect of group feeding on an abundant food source enables sea urchins in this zone to grow and reproduce at a high rate despite high densities (Meidel \& Scheibling 1998a,b). The formation of grazing fronts initiates a large-scale transition in community state, as fronts advance into the kelp bed and create, in their wake, barren grounds dominated by coralline algae (Bernstein et al. 1981, Johnson \& Mann 1986, Chapman \& Johnson 1990). This transition from the kelp bed state to the barrens state occurs within about a decade in Nova Scotia (Breen \& Mann 1976a, Scheibling et al. 1999). After the destruction of kelp beds, sea urchins in barrens remain relatively abundant but their nutritional state deteriorates, leading to declines in growth and gonad production (Lang \& Mann 1976, Meidel \& Scheibling 1998a,b). The subtidal zone persists in the barrens state until sea urchins are eliminated by disease (Miller 1985, Scheibling 1986). The ensuing reduction in grazing pressure results in rapid growth of macroalgae, and kelp beds are reestablished within 2 to 3 yr (Scheibling 1986, Novaczek \& McLachlan 1986, Johnson \& Mann 1988). Following mass mortalities, sea urchins begin to recolonize the developing kelp beds via larval settlement (Miller 1985, Raymond \& Scheibling 1987), but the recovery of adult populations may be limited by intensive predation on recruits (Scheibling 1996). The mechanisms causing population outbreaks of $S$. droebachiensis have not yet been conclusively demonstrated, but increased survival of the planktonic larvae (Hart \& Scheibling 1988) and migration of sea urchins from deeper waters into the shallows (Scheibling et al. 1999) have been hypothesized. The role of variation in zygote production in initiating outbreaks has not been explored.

In this paper, we use mathematical models to predict the number of eggs spawned by Strongylocentrotus droebachiensis per unit area, and on a coastal scale, in kelp beds, barrens, and grazing fronts along the Atlantic coast of Nova Scotia. We parameterize these models using sea urchin population data obtained from the literature and unpublished observations. We also estimate the relative contributions of sea urchins in these different habitats to the overall number of eggs 
spawned in this region during the transition from kelp beds to barrens. Our goal is to use our estimates of egg spawning and published estimates of fertilization rates to determine spatial and temporal variation in zygote production and to evaluate the importance of this variation to the population dynamics of $S$. droebachiensis along this coast.

\section{MODEL CONSTRUCTION AND PARAMETER ESTIMATION}

\section{Density and demography of subpopulations}

Fluctuations in populations of Strongylocentrotus droebachiensis, and hence in community state, occur along much of the Atlantic coast of Nova Scotia, where disease outbreaks periodically eliminate sea urchins (Miller 1985, Scheibling 1986, Scheibling \& Hennigar 1997; Fig. 1). In our model we include 3 different community states and the associated sea urchin subpopulations in this region of coast: (1) the established kelp bed state, with sea urchins in kelp beds; (2) the transition state, with sea urchins in kelp beds, transitional barrens, and grazing fronts; and (3) the barrens state, with sea urchins in post-transitional barrens. These community states generally succeed each other in any one area but also can occur simultaneously in different areas. We also consider the other transition state when kelp beds develop following a mass mortality of sea urchins. Although sea urchins recruit to the developing kelp beds, this state is distinguished from the established kelp bed state by the absence of adult sea urchins and therefore is not included in our model. We use the term 'subpopulation' for sea urchins in a particular habitat (kelp beds, transitional or post-transitional barrens) or zone (grazing fronts) in the ecological sense, not implying genetic differentiation.

To parameterize our model, we compile data on the population density, the proportion of adults, and the mean and maximum body size of adults in each of the 3 subpopulations we consider (Table 1). These data come from investigations on populations of Strongylocentrotus droebachiensis along the Atlantic coast of Nova Scotia over a 25 yr period. We estimate the proportion of adults and the mean size and maximum adult size from recorded size-frequency distributions which we reconstruct (where necessary) in $5 \mathrm{~mm}$ size classes. The proportion of adults depends on the size (test diameter) at first reproduction, which ranges between 18 and $25 \mathrm{~mm}$ in $S$. droebachiensis (Vadas 1977, Thompson 1979, Scheibling 1986, Raymond \& Scheibling 1987, Munk 1992). Because sea urchins tend to reproduce earlier in life, and therefore at a smaller size, in a nutritionally rich environment
(Buchanan 1966, Sivertsen \& Hopkins 1995, Meidel \& Scheibling 1999), we use $20 \mathrm{~mm}$ as the size at first reproduction in kelp beds and grazing fronts, and $25 \mathrm{~mm}$ in transitional and post-transitional barrens. Mean adult size is estimated by multiplying the midpoint of each $5 \mathrm{~mm}$ size class by the proportion of adult sea urchins in that class and summing the resulting values over all adult size classes.

\section{Egg spawning}

\section{Eggs spawned per unit area}

We calculate the total number of eggs spawned $(O)$ per unit area $\left(U, \mathrm{~m}^{2}\right)$ in subpopulation $k$ (sea urchins in kelp beds, grazing fronts, transitional or post-transitional barrens) as the sum of the eggs spawned by females in all size classes of adults:

$$
O_{k}^{(U)}=\sum_{j} D_{k} a_{k} f p(j)_{k} \frac{E_{j}}{5.56 \times 10^{-7}}
$$

where $D$ is sea urchin density (no. $\mathrm{m}^{-2}$ ), $a$ is the proportion of adults, $f$ is the proportion of females, $p$ is the proportion of sea urchins in a $5 \mathrm{~mm}$ size class of adults denoted by its mid-point $j, E$ is fecundity (dry weight of eggs released, $g$ ) of a female sea urchin and $5.56 \times 10^{-7}$ is the dry weight per egg ( $g$, Thompson 1979). All symbols used in this and subsequent models are summarized in Table 2 .

Mean density and mean proportion of adults in each subpopulation (Table 3) are estimated from published data (Table 1). Because Strongylocentrotus droe-

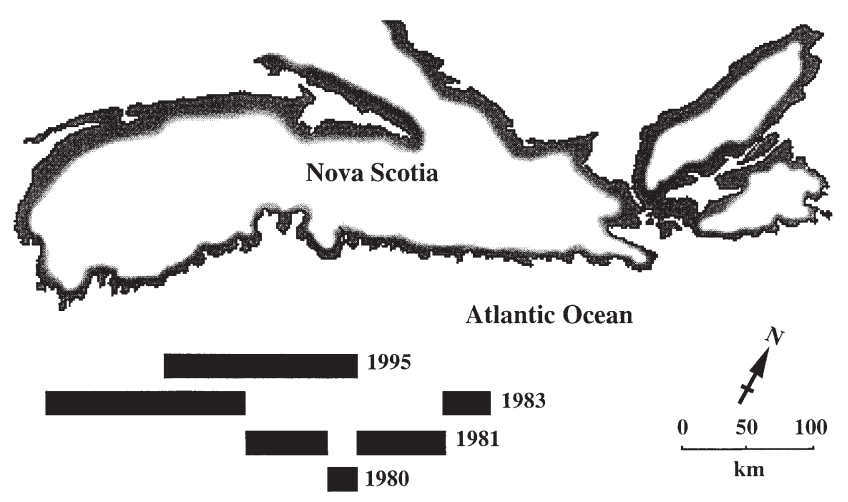

Fig. 1. Map of Nova Scotia showing the extent of mass mortalities of Strongylocentrotus droebachiensis during 1980 to 1983 and in 1995. Near-complete mass mortality is indicated by black bars. The maximum range of mass mortality (1983) denotes the extent of the shallow subtidal zone over which the number of eggs spawned and total zygote production is predicted. Gaps between bars in 1981 and 1983 indicate areas where sea urchins had been eliminated by disease in previous years. (Adapted from Scheibling \& Hennigar 1997) 
bachiensis usually has a sex ratio of 1:1 (Munk 1992, Meidel \& Scheibling 1998b), we set the proportion of females to 0.5 in all subpopulations (Table 3). The range of size classes of adults differs among subpopulations depending on the size at first reproduction (see 'Density and demography of subpopulations') and the

Table 1. Summary of published data on population density, proportion of adults, mean and maximum adult size of Strongylocentrotus droebachiensis in kelp beds, grazing fronts, transitional and post-transitional barrens along the Atlantic coast of Nova Scotia

\begin{tabular}{|c|c|c|c|c|c|c|}
\hline Location & $\begin{array}{l}\text { Sampling } \\
\text { period }\end{array}$ & $\begin{array}{l}\text { Population } \\
\text { density } \\
\left(\text { no. } \mathrm{m}^{-2}\right)\end{array}$ & $\begin{array}{l}\text { Proportion } \\
\text { of adults }\end{array}$ & $\begin{array}{c}\text { Mean } \\
\text { adult size } \\
(\mathrm{mm})\end{array}$ & $\begin{array}{l}\text { Maximum } \\
\text { adult size } \\
(\mathrm{mm})\end{array}$ & Source \\
\hline \multicolumn{7}{|l|}{ Kelp beds } \\
\hline St. Margaret's Bay & 1973 & 230 & 0.02 & 32.5 & 35 & Breen \& Mann (1976b) ${ }^{a}$ \\
\hline Boutilier Point & 1977 & 29.5 & & & & Chapman (1981) \\
\hline Boutilier Point & $10 / 1977-1 / 1980$ & 0 & & & & Bernstein et al. (1981) \\
\hline Coyle Cove & 6/1981 & 13 & 0.20 & 30.4 & 50 & Miller (1985a) \\
\hline Little Duck Island & 1992-1993 & 20 & 0.45 & 30.7 & 60 & Scheibling et al. $(1999)^{b}$ \\
\hline Mill Cove & 1992-1993 & 5 & 0.23 & 24.8 & 35 & Scheibling et al. (1999) \\
\hline \multicolumn{7}{|l|}{ Grazing fronts } \\
\hline St. Margaret's Bay & 1973 & & 0.73 & 37.2 & 55 & Breen \& Mann (1976a) \\
\hline St. Margaret's Bay & 1973 & 240 & 0.88 & 39.8 & 60 & Breen \& Mann (1976b) \\
\hline Clark's Harbour & $1978 / 79$ & 48 & 0.79 & 40.3 & 75 & Wharton \& Mann $(1981)^{c}$ \\
\hline Boutilier Point & 1978 & 50 & & & & Bernstein et al. $(1981)^{d}$ \\
\hline Little Duck Island & $1992-1993$ & 256 & 0.95 & 43.1 & 65 & Scheibling et al. $(1999)^{b}$ \\
\hline Mill Cove & 1992-1993 & 84 & 0.73 & 34.8 & 55 & Scheibling et al. (1999) \\
\hline \multicolumn{7}{|l|}{ Transitional barrens } \\
\hline St. Margaret's Bay & 1973 & 75 & 0.54 & 36.1 & 55 & Breen \& Mann (1976b) ${ }^{\mathrm{e}}$ \\
\hline Boutilier Point & $10 / 1977-1 / 1980$ & 18 & & & & Bernstein et al. $(1981)^{f}$ \\
\hline Eagle Head & $3 / 1983$ & 24 & 0.48 & 34.9 & 50 & Scheibling \& Stephenson (1984) \\
\hline Eagle Head & $3 / 1983$ & 26 & 0.71 & 32.9 & 50 & Scheibling \& Stephenson (1984) \\
\hline Coyle Cove & 6/1981 & 18 & 0.60 & 38.6 & 70 & Miller (1985) \\
\hline Little Duck Island & 1992-1993 & 80 & 0.20 & 33.4 & 60 & Scheibling et al. $(1999)^{b}$ \\
\hline Mill Cove & 1992-1993 & 48 & 0.18 & 31.4 & 50 & Scheibling et al. (1999) \\
\hline \multicolumn{7}{|l|}{ Post-transitional barrens $\mathbf{g}^{\mathrm{g}}$} \\
\hline Horse Island (2) & 1973 & 80 & 0.22 & 31.4 & 45 & Breen \& Mann (1976b) \\
\hline Luke Island (5) & 1973 & 110 & 0.04 & 30.3 & 35 & Breen \& Mann (1976b) \\
\hline Northwest Cove (1) & $5-9 / 1975$ & 50 & & & & Lang \& Mann (1976) \\
\hline Northwest Cove (3) & $5-9 / 1975$ & 70 & & & & Lang \& Mann (1976) \\
\hline Northwest Cove (4) & $5-9 / 1975$ & 95 & & & & Lang \& Mann (1976) \\
\hline Ingomar & $1978 / 79$ & 105.4 & 0.10 & 38.0 & 60 & Wharton (1980a) \\
\hline Port Mouton & $1978 / 79$ & 107.9 & 0.13 & 35.4 & 60 & Wharton (1980a) \\
\hline Blue Rocks & 1978/79 & 61.9 & 0.04 & 30.0 & 40 & Wharton (1980a) \\
\hline Northwest Cove & $1978 / 79$ & 67.5 & 0.13 & 30.8 & 50 & Wharton (1980a) \\
\hline Mushaboom & $1978 / 79$ & 55.0 & 0.58 & 32.6 & 55 & Wharton (1980a) \\
\hline Drum Head & $1978 / 79$ & 29.4 & 0.92 & 38.6 & 55 & Wharton (1980a) \\
\hline Dover & $1978 / 79$ & 45.6 & 0.71 & 30.7 & 50 & Wharton (1980a) \\
\hline Northwest Cove (1) & $5-9 / 1975$ & 53 & 0.64 & 33.4 & 50 & Wharton (1980a) \\
\hline Northwest Cove (4) & $5-9 / 1979$ & 96 & 0.23 & 29.3 & 40 & Wharton (1980a) \\
\hline Luke Island (5-6) & 1973 & 112 & 0.05 & 30.5 & 35 & Wharton (1980a) \\
\hline St. Margaret's Bay (8) & 1975 (?) & 43 & 0.09 & 31.9 & 45 & Wharton (1980a) \\
\hline St. Margaret's Bay (11-12) & $1970 \mathrm{~s}$ & 25 & 0.42 & 30.4 & 45 & Wharton (1980a) \\
\hline Louse Head & $8 / 1984$ & 89.3 & 0.45 & 41.0 & 60 & Scheibling (1986) \\
\hline Cape Mocodome & 8/1984 & 49.8 & 0.59 & 46.5 & 70 & Scheibling (1986) \\
\hline \multicolumn{7}{|c|}{$\begin{array}{l}\text { a Population density and proportion of adults from this study are not included in calculating the means of these } 2 \text { parameters } \\
\text { as they appear to be distorted by a heavy recruitment event }\end{array}$} \\
\hline \multicolumn{7}{|c|}{${ }^{b}$ Data from 1994 and 1995 are not used because of a mass mortality in fall 1993 at Little Duck Island } \\
\hline \multicolumn{7}{|l|}{${ }^{\mathrm{c}}$ Site $2 \mathrm{~b}$ in this study } \\
\hline \multicolumn{7}{|c|}{$\begin{array}{l}\text { dOnly data from July and December } 1978 \text { are used because densities in other months do not indicate the existence of a } \\
\text { grazing front }\end{array}$} \\
\hline \multicolumn{7}{|c|}{ eData collected $5 \mathrm{~m}$ from the edge of the kelp bed } \\
\hline \multicolumn{7}{|c|}{$\begin{array}{l}{ }^{f} \text { Data averaged from exposed and hidden sea urchins collected during the day } \\
\text { g Numbers in parenthesis indicate vears since kelp bed destruction }\end{array}$} \\
\hline & & & & & & \\
\hline
\end{tabular}


Table 2. List of symbols used

\begin{tabular}{|ll|}
\hline$a$ & Proportion of adults \\
$A$ & Total area occupied by a subpopulation \\
$B$ & Total wet body weight \\
$C$ & Constant in logistic Eq. (6) \\
$D$ & Population density \\
$E$ & Dry weight of eggs released \\
$f$ & Proportion of females \\
$F$ & Fertilization rate \\
$F_{0}$ & Fertilization rate in the absence of spawners \\
$F_{\mathrm{m}}$ & Asymptotic fertilization rate \\
$I$ & Proportion of total body wet weight that is gonads \\
$j$ & Size (mid-point of a size class) \\
$k$ & Subpopulation \\
$O^{(U)}$ & Number of eggs spawned per unit area by a subpop- \\
& ulation \\
$O^{(C)}$ & Number of eggs spawned on a coastal scale by a \\
& subpopulation \\
$O^{(T)}$ & Total number of eggs spawned on a coastal scale \\
$p(j)$ & Proportion of sea urchins in a size class of adults \\
$r$ & Proportion of spawning adults \\
$R$ & Proportion of $I$ that is spawned \\
$S$ & Density of spawners \\
$S$ & Proportional sensitivity (elasticity) \\
$V$ & Original model parameter in sensitivity analysis \\
$V^{*}$ & Altered model parameter in sensitivity analysis \\
$X$ & Original model output in sensitivity analysis \\
$X^{*}$ & Altered model output in sensitivity analysis \\
$Z^{(U)}$ & Number of zygotes produced per unit area by a \\
$Z^{(C)}$ & subpopulation \\
& Number of zygotes produced on a coastal scale by a \\
$Z^{(T)}$ & Total number of zygotes produced on a coastal scale \\
& \\
&
\end{tabular}

maximum size. For each subpopulation, the mean proportion of sea urchins in each size class of adults (Table 3) is estimated from the sources in Table 1 by summing the proportions in each class over all studies and dividing that sum by the total proportion in all adult classes. Because the proportion of sea urchins $>60 \mathrm{~mm}$ is low $(\leq 0.02)$ in all subpopulations, we use $55-60 \mathrm{~mm}$ as the largest size class.

Fecundity $(E)$ for size classes $j=22.5-57.5 \mathrm{~mm}$ in kelp beds and grazing fronts, and $j=27.5-57.5 \mathrm{~mm}$ in transitional and post-transitional barrens, is estimated from the spawned wet weight of gonads and a wet to dry weight conversion coefficient for gonads of Strongylocentrotus droebachiensis estimated by regression $\left(\mathrm{r}^{2}=0.970, \mathrm{n}=87\right)$ :

$$
E_{j, k}=0.249 I_{j, k} R_{k} B_{j}
$$

where $I$ is the maximum proportion of the total body wet weight that is gonads, $R$ is the proportion of gonad weight that is spawned, and $B(\mathrm{~g})$ is the total wet body weight. In kelp beds, grazing fronts and transitional barrens, we estimate $I$ (Table 3) from published data (Meidel \& Scheibling 1998b). Because $I$ increases with size in young adult sea urchins, we estimate $I$ for $j=$ 22.5-32.5 mm using a logistic equation given by Meidel \& Scheibling (1998b). For larger adults, $I$ is at an asymptotic level and is estimated as the average $I$ at the peak of the reproductive cycle, based on measurements over 2 yr and at 2 sites for each subpopulation (Meidel \& Scheibling 1998b). We assume that in posttransitional barrens $I$ is $30 \%$ of that in kelp beds (Lang \& Mann 1976). In kelp beds, grazing fronts and transitional barrens, we estimate $R$, the proportion of gonads spawned (Table 3), based on published data as the decrease in wet gonad mass directly after spawning (Meidel \& Scheibling 1998b). We assume that sea urchins in post-transitional barrens release the same proportion of gonadal material as those in transitional barrens. We estimate $B$ at each size $j$ using the following regression $\left(\mathrm{r}^{2}=0.995, \mathrm{n}=424\right.$; Scheibling et al. 1999):

$$
\ln B_{j}=2.81 \ln j-7.0
$$

\section{Eggs spawned on a coastal scale}

The number of eggs spawned $(O)$ on a coastal scale $(C)$ in subpopulation $k$ is calculated as

$$
O_{k}^{(C)}=O_{k}^{(U)} A_{k}
$$

where $A$ is the total area occupied by a subpopulation $\left(\mathrm{km}^{2}\right)$. The total number of eggs spawned by all subpopulations combined in the shallow rocky subtidal zone $(T)$ is calculated as

$$
O^{(T)}=\sum_{k} O_{k}^{(C)}
$$

We consider only subpopulations along that section of the coast of Nova Scotia where near-complete mass mortalities of Strongylocentrotus droebachiensis have been documented (Fig. 1). We also limit the offshore distribution of these subpopulations to a depth of $15 \mathrm{~m}$, where $>90 \%$ of the total algal biomass in this region is found (Mann 1972, Moore \& Miller 1983). The total area occupied by a subpopulation is estimated using surveys of the shallow (to $15 \mathrm{~m}$ depth) subtidal zone of the Atlantic coast of Nova Scotia by Moore \& Miller (1983) and Moore et al. (1986). These surveys determined the total area $\left(\mathrm{km}^{2}\right)$ that consisted of $>50 \%$ hard substratum and was deemed suitable habitat for sea urchins and macroalgae. The section of the coast we consider includes the entire area surveyed by Moore \& Miller (1983), which they estimate to have hard substratum covering $512 \mathrm{~km}^{2}$. Of the area surveyed by Moore et al. (1986), only the portion of eastern Halifax 
Table 3. Basic parameters used to calculate the number of eggs spawned and zygotes produced per unit area in kelp beds, grazing fronts, transitional and post-transitional barrens

\begin{tabular}{|c|c|c|c|c|c|c|}
\hline Parameter & Symbol & Units & $\begin{array}{l}\text { Kelp } \\
\text { beds }\end{array}$ & $\begin{array}{l}\text { Grazing } \\
\text { fronts }\end{array}$ & $\begin{array}{c}\text { Transitional } \\
\text { barrens }\end{array}$ & $\begin{array}{l}\text { Post-transitional } \\
\text { barrens }\end{array}$ \\
\hline Population density (SE) & $D$ & no. $\mathrm{m}^{-2}$ & $14(5.3)$ & $136(46.4)$ & $41(10.1)$ & $71(6.4)$ \\
\hline Proportion of adults (SE) & a & & $0.29(0.09)$ & $0.82(0.04)$ & $0.45(0.07)$ & $0.33(0.07)$ \\
\hline Proportion of females & $f$ & & 0.50 & 0.50 & 0.50 & 0.50 \\
\hline Proportion of adults in size class & $p$ & & & & & \\
\hline $20-25 \mathrm{~mm}, j=22.5 \mathrm{~mm}$ & & & 0.409 & 0.123 & & \\
\hline $25-30 \mathrm{~mm}, j=27.5 \mathrm{~mm}$ & & & 0.243 & 0.133 & 0.288 & 0.338 \\
\hline $30-35 \mathrm{~mm}, j=32.5 \mathrm{~mm}$ & & & 0.161 & 0.172 & 0.323 & 0.232 \\
\hline $35-40 \mathrm{~mm}, j=37.5 \mathrm{~mm}$ & & & 0.059 & 0.157 & 0.206 & 0.165 \\
\hline $40-45 \mathrm{~mm}, j=42.5 \mathrm{~mm}$ & & & 0.089 & 0.146 & 0.097 & 0.128 \\
\hline $45-50 \mathrm{~mm}, j=47.5 \mathrm{~mm}$ & & & 0.026 & 0.131 & 0.057 & 0.077 \\
\hline $50-55 \mathrm{~mm}, j=52.5 \mathrm{~mm}$ & & & 0.007 & 0.084 & 0.014 & 0.035 \\
\hline $55-60 \mathrm{~mm}, j=57.5 \mathrm{~mm}$ & & & 0.006 & 0.033 & 0.010 & 0.016 \\
\hline Proportion of total body weight that is gonads & $I$ & & & & & \\
\hline $20-25 \mathrm{~mm}, j=22.5 \mathrm{~mm}$ & & & 0.008 & 0.010 & & \\
\hline $25-30 \mathrm{~mm}, j=27.5 \mathrm{~mm}$ & & & 0.030 & 0.038 & 0.025 & 0.009 \\
\hline $30-35 \mathrm{~mm}, j=32.5 \mathrm{~mm}$ & & & 0.085 & 0.098 & 0.062 & 0.026 \\
\hline $35-40 \mathrm{~mm}, j=37.5 \mathrm{~mm}$ & & & 0.205 & 0.159 & 0.112 & 0.062 \\
\hline $40-45 \mathrm{~mm}, j=42.5 \mathrm{~mm}$ & & & 0.205 & 0.159 & 0.112 & 0.062 \\
\hline $45-50 \mathrm{~mm}, j=47.5 \mathrm{~mm}$ & & & 0.205 & 0.159 & 0.112 & 0.062 \\
\hline $50-55 \mathrm{~mm}, j=52.5 \mathrm{~mm}$ & & & 0.205 & 0.159 & 0.112 & 0.062 \\
\hline $55-60 \mathrm{~mm}, j=57.5 \mathrm{~mm}$ & & & 0.205 & 0.159 & 0.112 & 0.062 \\
\hline Proportion of gonad weight that is spawned & $R$ & & 0.70 & 0.72 & 0.77 & 0.77 \\
\hline Proportion of spawning adults & $r$ & & 0.33 & 0.33 & 0.33 & 0.33 \\
\hline Density of spawners & $s$ & no. $\mathrm{m}^{-2}$ & 1.3 & 37 & 6 & 8 \\
\hline
\end{tabular}

county $\left(\sim 27 \mathrm{~km}^{2}\right)$ is relevant here, which brings the total estimated area of suitable habitat for sea urchins and macroalgae to $539 \mathrm{~km}^{2}$.

When the shallow subtidal zone is in the established kelp bed or the barrens state, the entire area $(A)$ is occupied by sea urchins either in kelp beds or in posttransitional barrens. During the transition state, when large kelp beds are slowly grazed down and replaced by transitional barrens, we gradually decrease the area of kelp beds from 100 to $0 \%$ in $1 \%$ steps, and correspondingly increase the area of barrens. Following the removal of all kelp, transitional barrens change into post-transitional barrens relatively quickly. To account for this change, we decrease (increase) the area of transitional (post-transitional) barrens incrementally by $10 \%$ from the onset of the barrens state until the entire rocky subtidal zone is converted to post-transitional barrens.

The total area represented by grazing fronts on a coastal scale is estimated by assuming a front width of 2 m (Bernstein et al. 1981, Scheibling et al. 1999) along the entire length of the rocky coast. As grazing fronts may be convoluted or discontinuous along the edge of a kelp bed (pers. obs.), our estimate of the area represented by grazing fronts is a rough approximation. The surveys (Moore \& Miller 1983, Moore et al. 1986) give a total length of coastline suitable for sea urchins of $1609 \mathrm{~km}(1400 \mathrm{~km}$ for the southwestern shore and $209 \mathrm{~km}$ for eastern Halifax County). Based on these estimates of front width and length, the total area occupied by grazing fronts is $\sim 3.2 \mathrm{~km}^{2}$. This area is assumed to be constant during most of the transition state, and subtracted from the estimated area of transitional barrens. Because grazing fronts form and disperse over time, we incrementally increase the area occupied by this subpopulation in the early stages of the transition state by $10 \%$ and similarly decrease it in the early stages of the barrens state.

\section{Fertilization rate}

We estimate the fertilization rate in each subpopulation based on Wahle \& Peckham's (1999) field experiments on the effect of Strongylocentrotus droebachiensis density $\left(2.25,36\right.$, and 144 sea urchins $\left.\mathrm{m}^{-2}\right)$ on fertilization rate in weak currents (speed $<5 \mathrm{~cm} \mathrm{~s}^{-1}$ ) and in the absence of macroalgae. To estimate fertilization rates at the densities of spawners in our subpopulations, we fit Wahle \& Peckham's data (as 
presented in their Fig. 6) with the following logistic function:

$$
F=\frac{F_{0} F_{\mathrm{m}}}{F_{0}+\left(F_{\mathrm{m}}-F_{0}\right) \mathrm{e}^{-c F_{\mathrm{m}} s}}
$$

where $F$ is fertilization rate $(\%), F_{0}$ is fertilization rate in the absence of spawners, $F_{\mathrm{m}}$ is asymptotic fertilization rate, $C$ is a constant and $s$ is spawner density (no. $\mathrm{m}^{-2}$ ). Wahle \& Peckham also determined the interactive effects of population density (2.25 and 36 sea urchins $\mathrm{m}^{-2}$ ) and macroalgal (Laminaria saccharina) cover on fertilizations in strong currents (mean speed \pm SE: $9.3 \pm 3.7 \mathrm{~cm} \mathrm{~s}^{-1}$ outside kelp cover). Because current speed and absence/presence of macroalgae had little effect on fertilizations at the low population density, our approach of estimating fertilization rates in kelp beds based on a weak current in the absence of macroalgae is appropriate.

The density of spawners ( $s$, Table 3 ) in each subpopulation is estimated based on population density $(D)$, the proportion of adults $(a)$, and the proportion of adults that spawn during 1 spawning event ( $r$, Table 3 ). Previous studies have shown that natural spawning events in Strongylocentrotus droebachiensis may involve only a small proportion of the population (Keats et al. 1987, Pearse et al. 1988). To account for spawning asynchrony, we multiply adult densities in the subpopulations by the proportion of adults that spawn during a spawning event (Table 3). This parameter is estimated as the mean proportion of adult sea urchins that were partially spawned or spent on a single sampling date during the peak of the main spawning season (March to May), pooled over kelp beds, grazing fronts and transitional barrens (Meidel \& Scheibling 1998b).

\section{Zygote production}

The number of zygotes produced $(Z)$ per unit area $(U)$ in subpopulation $k$ is estimated as

$$
Z_{k}^{(U)}=\frac{O_{k}^{(U)} F_{k}}{100}
$$

where $F$ is the fertilization rate (\%) estimated from Wahle \& Peckham (1999) (see 'Fertilization rate' above).

The number of zygotes produced $(Z)$ on a coastal scale $(C)$ in subpopulation $k$ is estimated as

$$
Z_{k}^{(C)}=Z_{k}^{(U)} A_{k}
$$

The total number of zygotes produced by all subpopulations combined in the shallow rocky subtidal zone $(T)$ is calculated as

$$
Z^{(T)}=\sum_{k} Z_{k}^{(C)}
$$

\section{MODEL PREDICTIONS}

\section{Eggs spawned}

We estimate that the total number of eggs spawned per $\mathrm{m}^{2}$ (Eq. 1; Fig. 2) differs among subpopulations by more than 1 order of magnitude. It is highest in grazing fronts $\left(7.1 \times 10^{7}\right)$, intermediate in transitional and posttransitional barrens $\left(5.8 \times 10^{6}\right.$ and $4.4 \times 10^{6}$, respectively), and lowest in kelp beds $\left(1.0 \times 10^{6}\right)$.

The temporal variation in the number of eggs spawned by the different subpopulations on a coastal scale (Eq. 4; Fig. 3) is related to changes in the extent of the subtidal zone that these subpopulations occupy. Egg spawning in kelp beds is highest when the system is in the established kelp bed state $\left(5.6 \times 10^{14}\right)$ and declines at an accelerating rate as this habitat is destroyed during the transition state. In the expanding transitional barrens, egg spawning concomitantly increases to reach a maximum $\left(3.1 \times 10^{15}\right)$ late in the transition state once kelp beds have been destroyed. While grazing fronts are fully established, sea urchins in this zone occupy, according to our assumption, a constant area and spawn a constant number of eggs $\left(2.3 \times 10^{14}\right)$. In the post-transitional barrens after the fronts have dispersed, egg spawning $\left(2.4 \times 10^{15}\right)$ is somewhat lower than in transitional barrens but over 4-fold higher than in established kelp beds.

We predict total egg spawning by Strongylocentrotus droebachiensis in the shallow subtidal zone (Eq. 5; Fig. 3) to vary markedly in time depending on the community state. The number of eggs spawned is lowest in the established kelp bed state and progressively

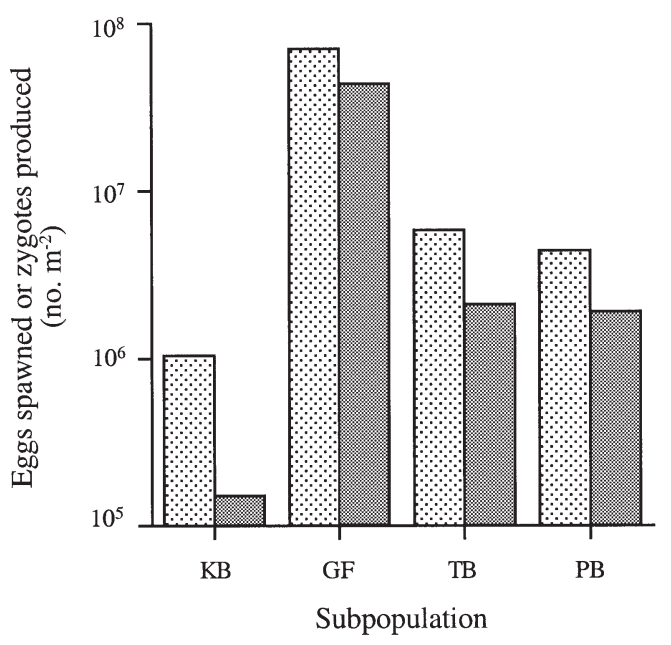

Fig. 2. Estimated number $\left(\mathrm{m}^{-2}\right)$ of eggs spawned (stippled bars) and zygotes produced (grey bars) in kelp beds (KB), grazing fronts (GF) and transitional (TB) and post-transitional (PB) barrens along the Atlantic coast of Nova Scotia 


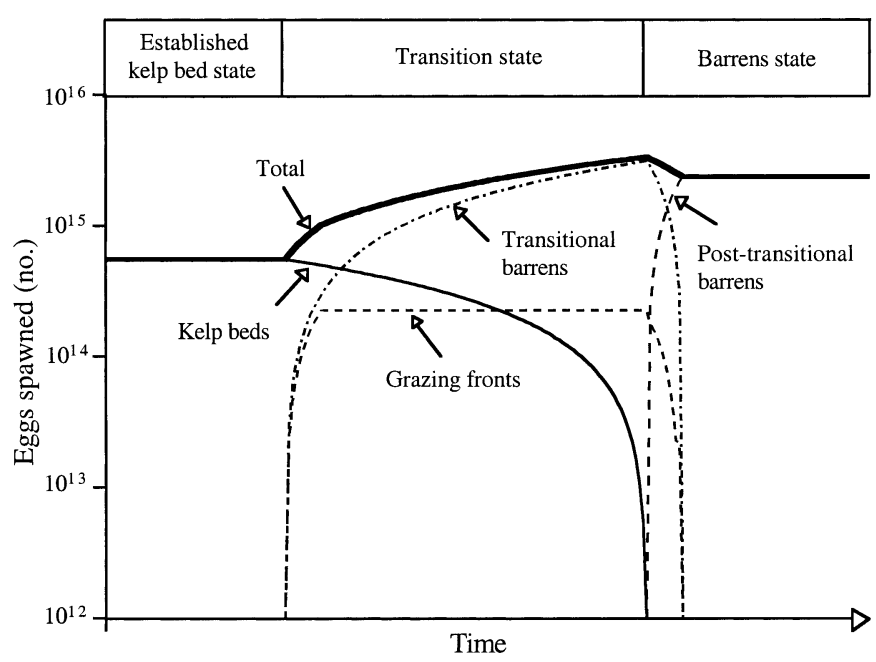

Fig. 3. Estimated number of eggs spawned in kelp beds, grazing fronts, transitional and post-transitional barrens on a coastal scale, and total number of eggs spawned in the entire subtidal zone (bold line, which partly overlaps with lines indicating the number of eggs spawned in kelp beds and post-transitional barrens), as the community moves from the established kelp bed via the transition to the barrens state over time

increases during the transition state as kelp beds are replaced by transitional barrens, reaching a maximum $\left(3.4 \times 10^{15}\right)$ just before grazing fronts disperse. Although sea urchins in fronts occupy $<1 \%$ of the total subtidal area, they contribute 7 to $22 \%$ of all eggs spawned during the transition state. As the entire sub-

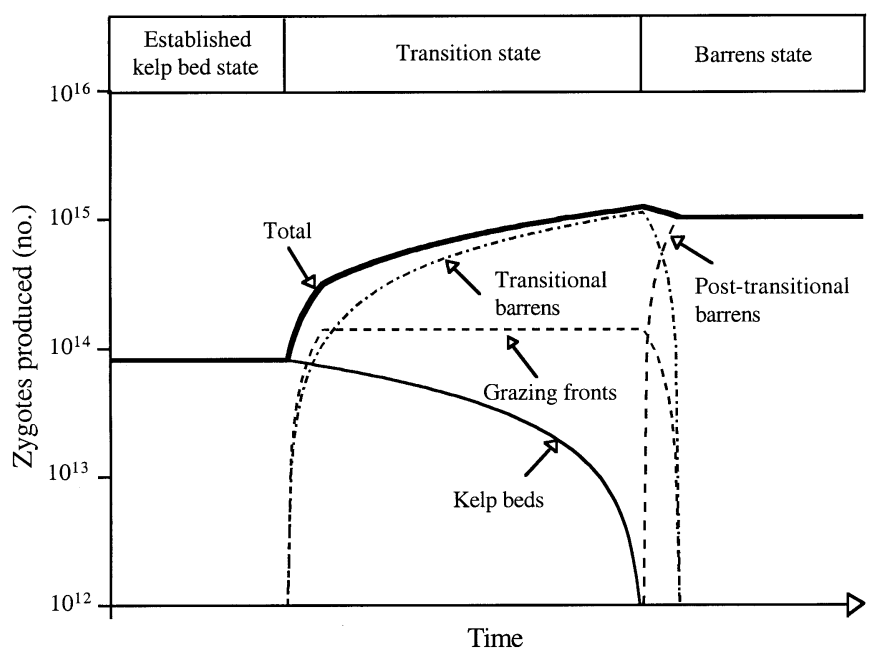

Fig. 4. Estimated number of zygotes produced in kelp beds, grazing fronts, transitional and post-transitional barrens on a coastal scale, and total number of zygotes produced in the entire subtidal zone (bold line, which partly overlaps with lines indicating the number of zygotes produced in kelp beds and posttransitional barrens), as the community moves from the established kelp bed via the transition to the barrens state over time tidal zone is converted to post-transitional barrens, total egg spawning drops by $\sim 30 \%$ (to $2.4 \times 10^{15}$ ) in the barrens state.

\section{Fertilization rate}

Based on Wahle \& Peckham's (1999) data, the parameters of the logistic function (Eq. 6) we use to estimate fertilization rates in the subpopulations are $F_{0}$, fertilization rate in the absence of spawners, $10.6 \%$; $F_{\mathrm{m}}$, asymptotic fertilization rate, $62 \%$; and $c_{1}$ a constant, -0.005 . The resulting curve provides a better fit to the data $\left(r^{2}=0.569\right)$ than Wahle \& Peckham's (1999) power function $\left(r^{2}=0.485\right.$; their Fig. 6$)$. The estimate of $10.6 \%$ for the fertilization rate in the absence of spawners is clearly an overestimate which resulted from the particular distribution of data points (12 to 20 fertilization rates at each of 3 densities). The adequacy of our parameter estimates is confirmed, however, by the good match between the fertilization rates estimated from the logistic function $(18 \%$ at 2.25 sea urchins $\mathrm{m}^{-2}$, and $62 \%$ at both 36 and 144 sea urchins $\mathrm{m}^{-2}$ ) and the mean fertilization rates measured by Wahle \& Peckham $(18,62$ and $61 \%$, respectively; their Fig. 5). Using the logistic function, we estimate that fertilization rates vary more than 4 -fold among subpopulations. The rate is highest in grazing fronts $(62.0 \%)$, intermediate in transitional and post-transitional barrens (36.1 and $43.3 \%$, respectively), and lowest in kelp beds (14.6\%).

\section{Zygote production}

The number of zygotes produced per $\mathrm{m}^{2}$ (Eq. 7 ; Fig. 2) differs among subpopulations by more than 2 orders of magnitude. It is highest in grazing fronts $\left(4.4 \times 10^{7}\right)$, intermediate in transitional and post-transitional barrens $\left(2.1 \times 10^{6}\right.$ and $1.9 \times 10^{6}$, respectively), and lowest in kelp beds $\left(1.5 \times 10^{5}\right)$.

Like egg spawning, zygote production by the different subpopulations on a coastal scale (Eq. 8; Fig. 4) shows temporal variation that is again related to changes in the extent of the subtidal zone that these subpopulations occupy. Zygote production in kelp beds is highest when the system is in the established kelp bed state $\left(8.1 \times 10^{13}\right)$ and declines at an accelerating rate as this habitat is destroyed during the transition state. In grazing fronts, zygote production is constant $\left(1.4 \times 10^{14}\right)$, while in transitional barrens it increases to a maximum $\left(1.1 \times 10^{15}\right)$ late in the transition state once kelp beds have been destroyed. Zygote production is slightly lower $\left(1.0 \times 10^{15}\right)$ in post-transitional than in transitional barrens but more than 1 
order of magnitude higher than in established kelp beds.

Like total egg spawning, total zygote production by Strongylocentrotus droebachiensis in the shallow subtidal zone (Eq. 9; Fig. 4) is estimated to vary markedly in time depending on the community state. Total zygote production is at a minimum in the established kelp bed state and progressively increases as kelp beds are replaced by transitional barrens, reaching a maximum $\left(1.3 \times 10^{15}\right)$ just before grazing fronts disperse. Sea urchins in grazing fronts contribute 11 to $44 \%$ of all zygotes produced during the transition state. As the entire subtidal zone is converted to posttransitional barrens, total zygote production drops by $16 \%$ (to $1.1 \times 10^{15}$ ) in the barrens state.

\section{SENSITIVITY ANALYSIS}

We analysed mean proportional sensitivity $(S$, also termed elasticity) based on all 4 subpopulations to measure how sensitive a model output is to small changes in basic parameters:

$$
S=\frac{1}{4} \sum_{k} \frac{\frac{X_{k}^{*}-X_{k}}{X_{k}}}{\frac{V_{k}^{*}-v_{k}}{V_{k}}}
$$

where $X^{*}$ is the output of the altered model, $X$ is the output of the original model, $V^{*}$ is the parameter value increased by a small amount, and $V$ is the original parameter value. A proportional sensitivity of 1 means that the model output increases by the same proportion by which the parameter value is increased. Sensitivity analysis indicates which parameters need to be most carefully estimated to obtain accurate model predictions. For our purposes, the analysis also indicates which parameters may be important for explaining differences in model output among subpopulations.

We calculated the effect of an increase in a basic parameter by $1 \%$ on the number of eggs spawned per unit area, $\left(O_{k}^{(U)}\right.$, Eq. 1) and on fertilization rate $(F$, Eq. 6). Basic parameters for $O_{k}^{(U)}$ were population density $(D)$ and the proportion of: adults $(a)$, females $(f)$, body weight that is gonads $(I)$, gonad weight that is spawned $(R)$, and females in a size class $(p(j))$, respectively. To determine the effect of an increase in the proportion of females in a size class, we increased this proportion in 1 size class by $1 \%$ and decreased the proportion in each of the other size classes in proportion to the abundance in that class. Basic parameters for $F$ were population density $(D)$, the proportion of adults (a), and the proportion of adults that spawn during a spawning event $(r)$. Only 1 parameter was varied in each analysis.
We estimated the proportion of spawning adults based on the proportion of adult sea urchins that were partially spawned or spent on a single sampling date. Because there was a 1 mo interval between that sample and the previous one, this estimate reflects the proportion of adult sea urchins that had spawned over a month. As a result, we may overestimate $r$ during the short time interval over which fertilizations are likely to occur. To determine how a potential overestimate of $r$ may affect fertilization rate, we calculated the reduction in $F$ when the proportion of adult spawners was reduced to 0.17 and to 0.08 (i.e. representing 2 and 4 spawning events within the 1 mo period; a reduction in $r$ by 50 and $75 \%$, respectively).

Our analysis indicated that the sensitivity of the number of eggs spawned per unit area was identical ( $S$ \pm SE: $1.0 \pm 0.0$ ) for increases in population density and in the proportion of adults, females, body weight that is gonads, and gonad weight that is spawned, respectively. Sensitivity was variable, and generally low, to changes in the proportions of females in a size class of adults (Fig. 5). The sensitivity to an increase in the proportions of females in the 2 smallest size classes was intermediate $(-0.41 \pm 0.26$ and $-0.31 \pm 0.07$ for $j=22.5$ and $27.5 \mathrm{~mm}$, respectively), while sensitivities to increases in other size classes were low $(-0.14 \pm 0.04$ to $0.06 \pm 0.01)$.

The sensitivity of fertilization rate was identical $(S \pm$ SE: $0.46 \pm 0.19$ ) for increases in population density, the proportion of adults, and the proportion of adults that spawn during a spawning event. A reduction in the proportion of spawning adults by $50 \%$ to account for the

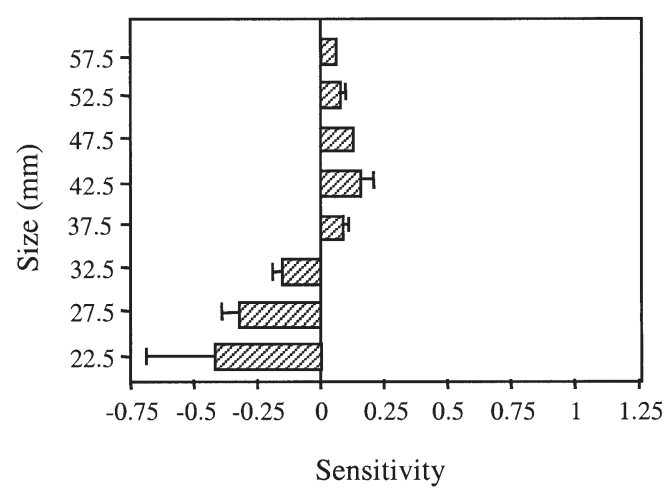

Fig. 5. Mean $( \pm \mathrm{SE})$ sensitivity of the number of eggs spawned per unit area to a small change in the proportion of females in a size class (represented by its mid-point) of adults. Means at $22.5 \mathrm{~mm}$ are based on sensitivities calculated in kelp beds and grazing fronts, while means at all other sizes are based on sensitivities calculated in all 4 subpopulations (kelp beds, grazing fronts, transitional and post-transitional barrens). Proportional sensitivities shown here are equal to the proportional change in the number of eggs spawned when the proportion of females is increased by $1 \%$ 
possibility of 2 spawning events within a 1 mo period reduced fertilization rates by $14 \%$ (to $12.5 \%$ ) in kelp beds, by $2 \%$ (to $61.0 \%$ ) in grazing fronts, by $40 \%$ (to $21.6 \%$ ) in transitional barrens, and by $50 \%$ (to $25.3 \%$ ) in post-transitional barrens. A reduction in the proportion of spawning adults by $75 \%$ to account for the possibility of 4 spawning events within a 1 mo period reduced fertilization rates by $21 \%$ (to $11.5 \%$ ) in kelp beds, by $22 \%$ (to $48.2 \%$ ) in grazing fronts, by $57 \%$ (to $15.5 \%$ ) in transitional barrens, and by $61 \%$ (to $17.0 \%$ ) in post-transitional barrens. These reductions in fertilization rates correspond to intermediate sensitivities of $0.49 \pm 0.20$ for a $50 \%$ reduction in the proportion of spawning adults and of $0.54 \pm 0.14$ for a $75 \%$ reduction.

\section{DISCUSSION}

\section{Model assumptions and parameterization}

The accuracy of our model predictions depends on both the accuracy of parameter estimates and the validity of assumptions. In this section, we consider the accuracy of certain estimates of model parameters, and we evaluate the validity of 2 important assumptions and whether they are equally valid for all subpopulations. This assessment will indicate the extent to which our predictions are accurate in an absolute or relative (i.e. among subpopulations) sense. Finally, we also consider the effect of omitting deeper-water populations from our models.

Sensitivity analysis indicates that the accuracy of the predictions of our egg spawning model depends largely on the accuracy of estimates of population parameters. We estimate these parameters based on several studies of populations of Strongylocentrotus droebachiensis along the Atlantic coast of Nova Scotia. Although absolute parameter values may vary over time and space within subpopulations, the rank order of those values among subpopulations is likely correct. Therefore, our models should accurately predict the relative numbers of eggs spawned by different subpopulations.

In an extension of our models of egg spawning, we estimate fertilization rates and the number of zygotes produced by subpopulations of Strongylocentrotus droebachiensis off the coast of Nova Scotia. The approach we use to approximate the proportion of spawning adults may overestimate that parameter. In nature, spawning of $S$. droebachiensis has only been observed outside the major spawning season when it involved a small percentage of the population (up to $15 \%$, Keats et al. $1987 ; 5 \%$, Pearse et al. 1988). Spawning by a low number of individuals has previously been reported for other sea urchins (Pennington 1985, Levitan 1988b), although 'mass spawning' has been observed in $S$. pur- puratus, an unidentified sea urchin (Pennington 1985), and Evechinus chloroticus (Lamare \& Stewart 1998). When we reduce the proportion of spawning adults to 0.17 and to 0.08 (i.e. to proportions similar to what has been observed in the field), estimated fertilization rates in the different subpopulations decrease by 2 to $50 \%$ or by 21 to $61 \%$, respectively, suggesting that an overestimate of this parameter would have a marked influence on the estimated number of zygotes produced.

Our estimates of fertilization rates may be affected also by variability in the hydrodynamic regime. In the shallow subtidal zone, current velocity varies in space and time as different types of currents (tidal or wind driven) interact with one another. We estimate fertilization rates in the subpopulations based on field experiments conducted in a weak current $\left(<5 \mathrm{~cm} \mathrm{~s}^{-1}\right.$; Wahle \& Peckham 1999). If sea urchins spawn at stronger current speeds, fertilization rates are likely to decline because of increased gamete dilution rates (e.g. Pennington 1985, Denny \& Shibata 1989, Levitan \& Young 1995). Wahle \& Peckham (1999) demonstrated a decline in fertilizations from 62 to $17 \%$ outside kelp cover as current speed increased $\sim 2$-fold, although this effect was noted only at a density of 36 spawners $\mathrm{m}^{-2}$ (not at $2.25 \mathrm{~m}^{-2}$ ). Therefore, if sea urchins spawn in currents much greater than $5 \mathrm{~cm} \mathrm{~s}^{-1}$, we may be overestimating fertilization rates, and consequently the number of zygotes produced. Because this overestimate is more likely to occur in grazing fronts (where the density is 37 spawners $\mathrm{m}^{-2}$ ) than in other subpopulations ( 1.3 to 8 spawners $\mathrm{m}^{-2}$ ), our estimated level of zygote production by individual subpopulations may be inaccurate in a relative (i.e. among subpopulations) sense. If this is the case, our estimated level of total zygote production also may be inaccurate in an absolute sense.

Our estimates of egg spawning and the contribution of different subpopulations to the overall zygote pool are limited to the shallow subtidal zone above $15 \mathrm{~m}$ depth. Although the abundance and size of Strongylocentrotus droebachiensis declines considerably at greater depths (Propp 1977, Logan et al. 1984, Martin et al. 1988), no information is available on the reproductive output or demography of these populations. Also, no measures exist on the extent of hard substratum below $15 \mathrm{~m}$ depth along the Atlantic coast of Nova Scotia. Therefore, we cannot evaluate the potential of deeperwater populations for egg spawning (or zygote production). While populations below $30 \mathrm{~m}$ are likely to have a low reproductive output due to a lack of macroalgal food, those at intermediate depths (15 to $30 \mathrm{~m}$ ) may spawn a considerable number of eggs as their food supply is augmented by drift algae from the shallows. It is thus likely that we are underestimating total egg spawning in the subtidal zone, especially during the es- 
tablished kelp bed state when the reproductive potential of deeper-living populations may be enhanced by inputs of drift algae (Scheibling et al. 1999).

Our evaluation of assumptions and sensitivity analysis suggest that our estimates of egg spawning are likely to be accurate in a relative sense although absolute numbers may be inaccurate. Our estimates of fertilization rates, and thus levels of zygote production, in the different subpopulations are most influenced by potential variability in spawning synchrony and in hydrodynamic conditions. Total egg spawning and zygote production on a coastal scale may be underestimated due to the omission of sea urchins at depths $>15 \mathrm{~m}$. To improve model predictions, we need to obtain a better estimate of spawning synchrony, determine under which flow conditions Strongylocentrotus droebachiensis are most likely to occur and spawn, and collect reproductive and demographic data on sea urchin populations at depths $>15 \mathrm{~m}$.

\section{Variation in the number of eggs spawned}

The predicted number of eggs spawned per $\mathrm{m}^{2}$ was influenced equally by changes in population density, and in the proportions of adults, females, body weight that is gonads, and gonad weight that is spawned (as indicated by sensitivity analysis). Sea urchins in grazing fronts release the largest number of eggs per unit area because extremely high densities of large females spawn a high proportion of their relatively large gonads. In transitional and post-transitional barrens, where females are less dense and smaller, and have a smaller gonad output than in grazing fronts, the predicted number of eggs spawned per unit area is about 1 order of magnitude lower than in fronts. In kelp beds, where relatively small females occur at very low densities, the predicted number of eggs spawned per unit area drops to about one-fifth of that spawned in barrens. In a study of variation in the gonad output of Strongylocentrotus droebachiensis at different depths (0 to $18 \mathrm{~m}$ ), Keats et al. (1984) estimated that sea urchins in kelp beds produced a gamete biomass per unit area $\left(12 \mathrm{~g} \mathrm{~m}^{-2}\right)$ that was similar to or less than that produced by sea urchins at higher densities in barrens at greater depths (9 to $49 \mathrm{~g} \mathrm{~m}^{-2}$ ).

The contribution of each subpopulation to the total number of eggs spawned on a coastal scale is determined largely by the extent of the subtidal zone that a given subpopulation occupies. As a result, sea urchins in grazing fronts, which spawn the largest number of eggs per unit area but occupy $<1 \%$ of the rocky subtidal zone, generally spawn fewer eggs in total than sea urchins in other subpopulations. For sea urchins in kelp beds and transitional barrens, egg spawning decreases or increases respectively, as kelp beds are destroyed by grazing fronts and replaced with barrens during the transition state. The total number of eggs spawned on a coastal scale increases approximately 6 -fold from the established kelp bed state to a peak in the late transition state before sea urchins in grazing fronts disperse. In post-transitional barrens, 4 times more eggs are spawned than in the former kelp beds.

Although numerous studies have determined the number of eggs produced by free-spawners either per individual (e.g. Thompson 1979, Scheibling \& Lawrence 1982, Kettle \& Lucas 1987, McShane et al. 1996) or per unit area (Coma et al. 1995, Coma \& Lasker 1997), few attempts have been made to estimate the total number of eggs produced by an entire population (Coma \& Lasker 1997). Little information exists on variation in egg spawning among populations of different size or demography. Our model predictions suggest that both the size and demography, i.e. structure of a population, must be taken into account when estimating the number of eggs that it spawns. Because egg spawning in combination with fertilization success determines zygote production, it is crucial to establish how egg spawning varies temporally and spatially when assessing how populations may vary in their contribution to the total zygote pool.

\section{Variation in fertilization rate}

Sensitivity analysis indicates that the estimated fertilization rate is similarly sensitive to changes in population density, in the proportion of adults, and in the proportion of adults that spawn during a spawning event. We assume that the proportion of spawning adults is identical in all subpopulations. The other 2 parameters, however, vary markedly among subpopulations of Strongylocentrotus droebachiensis (Table 3), resulting in a 4 -fold difference in estimated fertilization rates. Fertilization rate is highest $(62 \%)$ for sea urchins in grazing fronts where adults occur at extremely high densities (i.e. at small distances between spawners). In barrens, where adult densities are lower, fertilization rates are estimated to be intermediate (36 and $43 \%$ in transitional and post-transitional barrens, respectively). In kelp beds, the low density of adults causes the fertilization rate to drop to the lowest level (15\%).

\section{Variation in zygote production and sea urchin population dynamics}

Because estimated fertilization rates differ between subpopulations by up to a factor of 4 (between sea urchins in grazing fronts and in kelp beds), estimated 
variation in zygote production per unit area among subpopulations of Strongylocentrotus droebachiensis is more pronounced than variation in the number of eggs spawned. The contribution of each subpopulation to total zygote production on a coastal scale is, however, still determined largely by the extent of the subtidal zone that a given subpopulation occupies. As a result, the general patterns of egg spawning and zygote production on a coastal scale are similar. Although sea urchins in grazing fronts still produce generally fewer zygotes than sea urchins in other subpopulations, a high fertilization rate enables them to make a significantly larger contribution to the overall zygote pool than to the overall egg pool (11 to 44 vs 7 to $22 \%$ ). Because of the large variation in fertilization rate, there is an approximately 16 -fold increase in total zygote production from the established kelp bed state to the late transition state, compared to an approximately 6-fold increase in egg spawning during the same interval.

To assess the importance of variation in zygote production on the population dynamics of Strongylocentrotus droebachiensis along the Atlantic coast of Nova Scotia, we compare our estimate of zygote production with natural variation in settlement. On a coastal scale, we estimate that total zygote production in the shallow subtidal zone differs 16 -fold among community states that include adult sea urchins. Because no zygotes are produced in the shallow subtidal zone for at least $2 \mathrm{yr}$ after a sea urchin mass mortality, variation in total zygote production is even greater if we include the developing kelp bed state (from 0 to $\sim 10^{15} \mathrm{~m}^{-2}$ ). However, settlement can occur shortly after a sea urchin die-off (Miller 1985, Scheibling 1986, Raymond \& Scheibling 1987, Scheibling \& Raymond 1990) and can vary interannually by more than an order of magnitude during the transition from kelp beds to barrens (Balch $\&$ Scheibling 2000), when we predict a more gradual increase. This discrepancy between the temporal patterns of estimated zygote production and observed settlement rates suggests that settlement of $S$. droebachiensis in the shallow subtidal zone is not primarily determined by zygote production within that zone. Other important factors may include advective transport of larvae to and from the region (Scheltema 1986, Shanks 1995), and sea temperature which regulates the rate of larval development and hence survival in the plankton (Hart \& Scheibling 1988). Nevertheless, the estimated large increase in zygote production during the transition state may enhance settlement and thus sustain, or even accelerate, a sea urchin outbreak.

A clearer resolution of the importance of variation in egg spawning and fertilization rate, and consequently variation in zygote production, to population dynamics of Strongylocentrotus droebachiensis, relative to other biological and physical factors, requires further study. For example, longitudinal studies spanning different community states may elucidate the relationship between patterns of zygote production and the frequency and magnitude of settlement events. Genetic analysis of larvae and settlers also may be helpful in determining the origins of larvae settling along this coast (Medeiros-Bergen et al. 1995, Palumbi 1995). In particular, investigation of deep-water populations is needed to assess their contribution to the larval pool.

Acknowledgements. We thank M. Barbeau, B. Hatcher, A. Metaxas, C. Styan, R. Wahle, P. Yund, and 2 anonymous reviewers for critically reviewing earlier drafts of this manuscript. We are also grateful to R. Wahle for providing raw fertilization data. Funding was provided by an Izaak Walton Killam Memorial Scholarship (to S.K.M.), a Patrick Lett Bursary from Dalhousie University (to S.K.M.), a Natural Sciences and Engineering Research Council Research Grant (to R.E.S.), a Natural Science Foundation grant (OCE-97-30354, to P. O. Yund), and a Sea Urchin Zone Council Research Grant from the Maine Department of Marine Resources (to R. S. Steneck and R. A. Wahle). This is Darling Marine Center contribution no. 361.

\section{LITERATURE CITED}

Babcock RC, Mundy CN, Whitehead D (1994) Sperm diffusion models and in situ confirmation of long-distance fertilization in the free-spawning asteroid Acanthaster planci. Biol Bull 186:17-28

Balch T, Scheibling RE (2000) Temporal and spatial variability in settlement and recruitment of echinoderms in kelp beds and barrens in Nova Scotia. Mar Ecol Prog Ser 205: 139-154

Bernstein BB, Williams BE, Mann KH (1981) The role of behavioural responses to predators in modifying urchins' (Strongylocentrotus droebachiensis) destructive grazing and seasonal foraging patterns. Mar Biol 63:39-49

Branham JM, Reed SA, Bailey JH (1971) Coral-eating sea stars Acanthaster planci in Hawaii. Science 172: 1155-1157

Breen PA, Mann KH (1976a) Changing lobster abundance and the destruction of kelp beds by sea urchins. Mar Biol 34:137-142

Breen PA, Mann KH (1976b) Destructive grazing of kelp by sea urchins in eastern Canada. J Fish Res Board Can 33: $1278-1283$

Buchanan JB (1966) The biology of Echinocardium cordatum (Echinodermata: Spatangoidea) from different habitats. J Mar Biol Assoc UK 46:97-114

Chapman ARO (1981) Stability of sea urchin dominated barren grounds following destructive grazing of kelp in St. Margaret's Bay, eastern Canada. Mar Biol 62:307-311

Chapman ARO, Johnson CR (1990) Disturbance and organization of macroalgal assemblages in the Northwest Atlantic. Hydrobiologia 192:77-121

Coma R, Lasker HR (1997) Effects of spatial distribution and reproductive biology on in situ fertilization rates of a broadcast-spawning invertebrate. Biol Bull 193:20-29

Coma R, Zabala M, Gili JM (1995) Sexual reproductive effort in the Mediterranean gorgonian Paramuricea clavata. Mar Ecol Prog Ser 117:185-192 
Denny MW, Shibata MF (1989) Consequences of surf-zone turbulence for settlement and external fertilization. Am Nat 134:859-889

Edelstein T, Craigie JS, McLachlan J (1969) Preliminary survey of the sublittoral flora of Halifax County. J Fish Res Board Can 26:2703-2713

Gonor JJ (1972) Gonad growth in the sea urchin, Strongylocentrotus purpuratus (Stimpson) (Echinodermata: Echinoidea) and the assumptions of gonad index methods. J Exp Mar Biol Ecol 10:89-103

Grosberg RK (1991) Sperm-mediated gene flow and the genetic structure of a population of the colonial ascidian Botryllus schlosseri. Evolution 45:130-142

Grosberg RK, Levitan DR (1992) For adults only? Supply-side ecology and the history of larval biology. Trends Ecol Evol 7:130-133

Hart MW, Scheibling RE (1988) Heat waves, baby booms, and the destruction of kelp beds by sea urchins. Mar Biol 99: 167-176

Johnson CR, Mann KH (1986) The crustose coralline alga, Phymatolithon Foslie, inhibits the overgrowth of seaweeds without relying on herbivores. J Exp Mar Biol Ecol 96: 127-146

Johnson CR, Mann KH (1988) Diversity, patterns of adaptation, and stability of Nova Scotian kelp beds. Ecol Monogr 58:129-154

Keats DW, Steele DH, South GR (1984) Depth-dependent reproductive output of the green sea urchin, Strongylocentrotus droebachiensis (O.F. Müller), in relation to the nature and availability of food. J Exp Mar Biol Ecol 80: 77-91

Keats DW, Hooper RG, Steele DH, South GR (1987) Field observations of summer and autumn spawning by Strongylocentrotus droebachiensis, green sea urchins, in eastern Newfoundland. Can Field Nat 101:463-465

Kettle BT, Lucas JS (1987) Biometric relationships between organ indices, fecundity, oxygen consumption and body size in Acanthaster planci (L.) (Echinodermata; Asteroidea). Bull Mar Sci 41:541-551

Lamare MD, Stewart BG (1998) Mass spawning by the sea urchin Evechinus chloroticus (Echinodermata: Echinoidea) in a New Zealand fjord. Mar Biol 132:135-140

Lang C, Mann KH (1976) Changes in sea urchin populations after the destruction of kelp beds. Mar Biol 36:321-326

Levitan DR (1988a) Density-dependent size regulation and negative growth in the sea urchin Diadema antillarum Philippi. Oecologia 76:627-629

Levitan DR (1988b) Asynchronous spawning and aggregative behaviour in the sea urchin Diadema antillarum (Philippi). In: Burke RD, Mladenov PV, Lambert P, Parsley RL (eds) Echinoderm biology. AA Balkema, Rotterdam, p 181-186

Levitan DR (1991) Influence of body size and population density on fertilization success and reproductive output in a free-spawning invertebrate. Biol Bull 181:261-268

Levitan DR (1995) The ecology of fertilization in free-spawning invertebrates. In: McEdward LR (ed) Ecology of marine invertebrate larvae. CRC Press, Inc, Boca Raton, p 123-156

Levitan DR, Young CM (1995) Reproductive success in large populations: empirical measures and theoretical predictions of fertilization in the sea biscuit Clypeaster rosaceus. J Exp Mar Biol Ecol 190:221-241

Levitan DR, Sewell MA, Chia FS (1992) How distribution and abundance influence fertilization success in the sea urchin Strongylocentrotus franciscanus. Ecology 73:248-254

Logan A, Page FH, Thomas MLH (1984) Depth zonation of epibenthos on sublittoral hard substrates off Deer Island,
Bay of Fundy, Canada. Estuar Coast Shelf Sci 18:571-592

Mann KH (1972) Ecological energetics of the seaweed zone in a marine bay on the Atlantic coast of Canada. I. Zonation and biomass of seaweeds. Mar Biol 12:1-10

Mann KH (1977) Destruction of kelp-beds by sea urchins: a cyclical phenomenon or irreversible degradation? Helgol Wiss Meeresunters 30:455-467

Martin PD, Truchon SP, Harris LG (1988) Strongylocentrotus droebachiensis populations and community dynamics at two depth-related zones over an 11-year period. In: Burke RD, Mladenov PV, Lambert P, Parsley RL (eds) Echinoderm biology. AA Balkema, Rotterdam, p 475-482

McShane PE, Gerring PK, Anderson OA, Stewart RA (1996) Population differences in the reproductive biology of Evechinus chloroticus (Echinoidea: Echinometridae). NZ J Mar Freshw Res 30:333-339

Medeiros-Bergen DE, Olson RR, Conroy JA, Kocher TD (1995) Distribution of holothurian larvae determined with species-specific probes. Limnol Oceanogr 40:1225-1235

Meidel SK, Scheibling RE (1998a) Size and age structure of the sea urchin Strongylocentrotus droebachiensis in different habitats. In: Mooi R, Telford M (eds) Echinoderms: San Francisco. AA Balkema, Rotterdam, p 737-742

Meidel SK, Scheibling RE (1998b) The annual reproductive cycle of the green sea urchin, Strongylocentrotus droebachiensis, in differing habitats in Nova Scotia, Canada. Mar Biol 131:461-478

Meidel SK, Scheibling RE (1999) Effects of food type and ration on reproductive maturation and growth of the sea urchin Strongylocentrotus droebachiensis. Mar Biol 134: 155-166

Miller RJ (1985) Succession in sea urchin and seaweed abundance in Nova Scotia, Canada. Mar Biol 84:275-286

Minchinton TE, Scheibling RE (1991) The influence of larval supply and settlement on the population structure of barnacles. Ecology 72:1867-1879

Moore DS, Miller RJ (1983) Recovery of macroalgae following widespread sea urchin mortality with a description of the nearshore hard-bottom habitat on the Atlantic coast of Nova Scotia. Can Tech Rep Fish Aquat Sci 1230

Moore DS, Miller RJ, Meade LD (1986) Survey of shallow benthic habitat: Eastern shore and Cape Breton, Nova Scotia. Can Tech Rep Fish Aquat Sci 1546

Munk JE (1992) Reproduction and growth of green sea urchins Strongylocentrotus droebachiensis (Müller) near Kodiak, Alaska. J Shellfish Res 11:245-254

Novaczek I, McLachlan J (1986) Recolonization by algae of the sublittoral habitat of Halifax county, Nova Scotia, following the demise of sea urchins. Bot Mar 29:69-73

Oliver J, Babcock R (1992) Aspects of the fertilization ecology of broadcast spawning corals: sperm dilution effects and in situ measurements of fertilization. Biol Bull 183: 409-417

Palumbi SR (1995) Using genetics as an indirect estimator of larval dispersal. In: McEdward LR (ed) Ecology of marine invertebrate larvae. CRC Press, Inc, Boca Raton, p 369-387

Pearse JS, Hines AH (1987) Long-term population dynamics of sea urchins in a central California kelp forest: rare recruitment and rapid decline. Mar Ecol Prog Ser 39: 275-283

Pearse JS, McClary DJ, Sewell MA, Austin WC, Perez-Ruzafa A, Byrne M (1988) Simultaneous spawning of six species of echinoderms in Barkley Sound, BC. Invertebr Reprod Dev 14:279-288

Pennington JT (1985) The ecology of fertilization of echinoid eggs: the consequences of sperm dilution, adult aggrega- 
tion, and synchronous spawning. Biol Bull 169:417-430

Propp MV (1977) Ecology of the sea urchin Strongylocentrotus droebachiensis of the Barents Sea: metabolism and regulation of abundance. Sov J Mar Biol 3:27-37

Raymond BG, Scheibling RE (1987) Recruitment and growth of the sea urchin Strongylocentrotus droebachiensis following mass mortalities off Nova Scotia, Canada. J Exp Mar Biol Ecol 108:31-54

Scheibling RE (1981) The annual reproductive cycle of Oreaster reticulatus (L.) (Echinodermata: Asteroidea) and interpopulation differences in reproductive capacity. J Exp Mar Biol Ecol 54:39-54

Scheibling RE (1986) Increased macroalgal abundance following mass mortalities of sea urchins (Strongylocentrotus droebachiensis) along the Atlantic coast of Nova Scotia. Oecologia 68:186-198

Scheibling RE (1996) The role of predation in regulating sea urchin populations in eastern Canada. Oceanol Acta 19: 421-430

Scheibling RE, Hennigar AW (1997) Recurrent outbreaks of disease in sea urchins Strongylocentrotus droebachiensis in Nova Scotia: evidence for a link with large scale meteorologic and oceanographic events. Mar Ecol Prog Ser 152: 155-165

Scheibling RE, Lawrence JM (1982) Differences in reproductive strategies of morphs of the genus Echinaster (Echinodermata: Asteroidea) from the eastern Gulf of Mexico. Mar Biol 70:51-62

Scheibling RE, Raymond BG (1990) Community dynamics on a subtidal cobble bed following mass mortalities of sea urchins. Mar Ecol Prog Ser 63:127-145

Scheibling RE, Stephenson RL (1984) Mass mortality of Strongylocentrotus droebachiensis (Echinodermata: Echinoidea) off Nova Scotia, Canada. Mar Biol 78:153-164

Scheibling RE, Hennigar AW, Balch T (1994) The dynamics of destructive grazing of kelp beds by sea urchins in Nova Scotia. In: David B, Guille A, Féral JP, Roux M (eds) Echinoderms through time. AA Balkema, Rotterdam, p 871

Scheibling RE, Hennigar AW, Balch T (1999) Destructive grazing, epiphytism, and disease: the dynamics of sea urchin-kelp interactions in Nova Scotia. Can J Fish Aquat Sci 56:2300-2314

Scheltema RS (1986) On dispersal and planktonic larvae of benthic invertebrates: an eclectic overview and summary of problems. Bull Mar Sci 39:290-322

Editorial responsibility: Ronald Karlson (Contributing Editor), Newark, Delaware, USA
Shanks AL (1995) Mechanisms of cross-shelf dispersal of larval invertebrates and fish. In: McEdward LR (ed) Ecology of marine invertebrate larvae. CRC Press, Inc, Boca Raton, p 323-367

Sivertsen K, Hopkins CCE (1995) Demography of the echinoid Strongylocentrotus droebachiensis related to biotope in northern Norway. In: Skjoldal HR, Hopkins C, Erikstad KE, Leinaas HP (eds) Ecology of fjords and coastal waters. Elsevier Science BV, Amsterdam, p 549-571

Thompson RJ (1979) Fecundity and reproductive effort in the blue mussel (Mytilus edulis), the green sea urchin (Strongylocentrotus droebachiensis), and the snow crab (Chionoecetes opilio) from populations in Nova Scotia and Newfoundland. J Fish Res Board Can 36:955-964

Vadas RL (1977) Preferential feeding: an optimization strategy in sea urchins. Ecol Monogr 47:337-371

Wahle RA, Peckham H (1999) Density-related reproductive trade-offs in the green sea urchin Strongylocentrotus droebachiensis. Mar Biol 134:127-137

Wharton WG (1980a) The relationship between destructive grazing by the sea urchin Strongylocentrotus droebachiensis and the abundance of American lobster Homarus americanus on the Atlantic coast of Nova Scotia. MSc thesis, Dalhousie University, Halifax, NS

Wharton WG (1980b) The distribution of sea urchin-dominated barren grounds along the south shore of Nova Scotia. In: Pringle JD, Sharp GJ, Caddy JF (eds) Proceedings of the workshop on the relationship between sea urchin grazing and commercial plant/animal harvesting. Can Tech Rep Fish Aquat Sci 954:33-47

Wharton WG, Mann KH (1981) Relationship between destructive grazing by the sea urchin, Strongylocentrotus droebachiensis, and the abundance of American lobster, Homarus americanus, on the Atlantic coast of Nova Scotia. Can J Fish Aquat Sci 38:1339-1349

Young CM, Tyler PA, Cameron JL, Rumrill SG (1992) Seasonal breeding aggregations in low-density populations of the bathyal echinoid Stylocidaris lineata. Mar Biol 113: 603-612

Yund PO (1995) Gene flow via the dispersal of fertilizing sperm in a colonial ascidian (Botryllus schlosseri): the effect of male density. Mar Biol 122:649-654

Yund PO (1998) The effect of sperm competition on male gain curves in a colonial marine invertebrate. Ecology 79: 328-339

Submitted: April 28, 1999; Accepted: November 20, 2000

Proofs received from author(s): March 12, 2001 